\title{
22. ASH FROM VITRIC MUDS IN DEEP SEA CORES FROM THE MARIANA TROUGH AND FORE-ARC REGION (SOUTH PHILIPPINE SEA) (SITES 453, 454, 455, 458, 459, AND SP), DEEP SEA DRILLING PROJECT LEG 601
}

\author{
Hans-Ulrich Schmincke, Institut für Mineralogie, Ruhr-Universität Bochum, Federal Republic of Germany
}

\begin{abstract}
Precisely determined refractive indices of glass shards from 32 ash-rich, volcaniclastic sediments, mostly turbidites interbedded with nonvolcanic sediments in the Mariana Trough, range from 1.480 to 1.585 (corresponding to $\mathrm{SiO}_{2}$ ca. 75 to $49 \%$ ), with most in the range 1.500 to $1.540\left(\mathrm{SiO}_{2} \mathrm{ca} .70-62 \%\right)$ and a second, smaller mode between ca. 1.560 and $1.585\left(57\right.$ to $\left.49 \% \mathrm{SiO}_{2}\right)$. Shards are almost exclusively colorless from 1.480 to ca. 1.530 , light brown with minor colorless and green tones between 1.530 and 1.560, and dominantly brown at higher refractive indices. Tubular pumice shards are more common at higher silica percentages and non- to poorly-vesicular cuniform shards at low $\mathrm{SiO}_{2}$ values, but there is no clear correlation between shape and composition of shards. About half of the samples have bimodal shard populations with silica differences ranging up to 20 percent; unimodal layers have a range of up to about 7 percent $\mathrm{SiO}_{2}$. Of 21 samples in which one type of shard dominates, seven have the main mode in the rhyolitic composition $\left(>69 \% \mathrm{SiO}_{2}\right)$, eight in the intermediate range ( 56 to $\left.69 \% \mathrm{SiO}_{2}\right)$, and five in mafic composition $\left(\mathrm{SiO}_{2}<53 \%\right)$. These unusually abundant mafic shards occur mainly in site survey piston cores, SP-IA and 4E, and in Holes 454, 456, 458, and 459B. These are the sites closest to the present arc.

Hole 453, containing by far the most vitric tuff turbidites, shows a gradual increase in silica content of ash layers upward to the hole from Cores 36 to 19 (about 4.6 to 3.0 Ma). A drastic decrease in ash-rich beds in the younger (Pleistocene) part of this hole was noted by the shipboard party (see site chapter, Site 453) and was interpreted by them as indicating increasing distance from the arc volcanoes as the trough opened. The increase in silica in ashes from the early to the late Pliocene at Site 453 could be interpreted in the same way and might indicate that the trough started to open in early Pliocene time.
\end{abstract}

\section{INTRODUCTION}

During Leg 60, 10 holes (Holes 452 through 461) were drilled by the Glomar Challenger along an east-west transect through the Mariana Trough, Mariana Arc, the Trench-arc gap, and the Mariana Trench (Figs. 1 and 2). Volcanic components are common in sediments from this environment; 32 samples from ash-rich beds from six holes (chiefly Site 453 ) were provided by the shipboard party for shorebased work. ${ }^{2}$ Information on the ash thickness and structures of the beds is included in pertinent site chapters. Microprobe determinations in progress were not ready for publication. This report mainly discusses petrographic data and R.I. (refractive index) measurements of vitric shards from these samples.

The purpose of this research is to assess the diversity of shards in sediments rich in ash, to infer the compositional nature of the eruptions, and to interpret some aspects of the volcanic and tectonic evolution of the area from the nature of the ash-rich beds.

\section{METHODS}

The samples supplied by the shipboard party, weighing from about 1.2 to $12.5 \mathrm{~g}$ (Table 1), were dried, weighed, and treated with $\mathrm{H}_{2} \mathrm{O}_{2}$ $(30 \%)$ and $\mathrm{HCl}(15 \%)$ to remove organic substances and carbonates. The insoluble residue was repeatedly rinsed with distilled water, dried, and weighed. Weight loss ranged from about 3 to 43 percent. Samples were dispersed in distilled water in an ultrasonic bath, and the fraction

\footnotetext{
${ }_{2}^{1}$ Initial Reports of the Deep Sea Drilling Project, Volume 60

${ }^{2}$ Most of the samples were from the coarser portions of graded turbidites shed from surrounding ridges.
}

$<63 \mu \mathrm{m}$ was removed by wet sieving, filtered, and dried. The coarser fraction was dried and sieved through $200-\mu \mathrm{m}$ and $125-\mu \mathrm{m}$ sieves. Only the fraction $65-125 \mu \mathrm{m}$ was used for further study. The relative proportion of glass versus other components, notably diatoms, was visually estimated under the binocular. Glass shards were separated with heavy liquids or picked by hand for refractive index measurements.

Refractive indices were determined accurately with methods described in detail by Schmincke and Medenbach (in preparation). Briefly, glass shards are glued on to a glass slide and immersed repeatedly in different immersion liquids-CARGIL. Refractive indices are determined using the wavelength variation method in combination with phase contrast. Phase contrast is especially useful for distinguishing subpopulations of glass shards differing from each other in R.I. Temperatures were controlled, and the index meàsurements have a precision of \pm 0.0005 (estimated).

\section{SAMPLE COMPOSITIONS}

Samples studied have a wide range of compositions. Two samples (Samples 454-3-4, 79-80 cm and 458-16-1, $47-48 \mathrm{~cm}$ ) contain no glass. Others range from almost pure glass to those with over 50 percent soluble organic and carbonatic material. The sorting ranges from good to excellent in the insoluble residue. Components other than glass are diatoms, radiolarians, sponge spicules, and heavy and light minerals.

\section{REFRACTIVE INDICES}

Glass shards in most samples have a wide range of refractive indices, with one type of glass being dominant (Table 1, Figs. 3 and 4 ) in 21 out of 32 samples studied. Of these, five are from samples with only small amounts of glass, suggesting the possibility that up to about one half of the samples studied might be composed of several shard populations without any one being most 


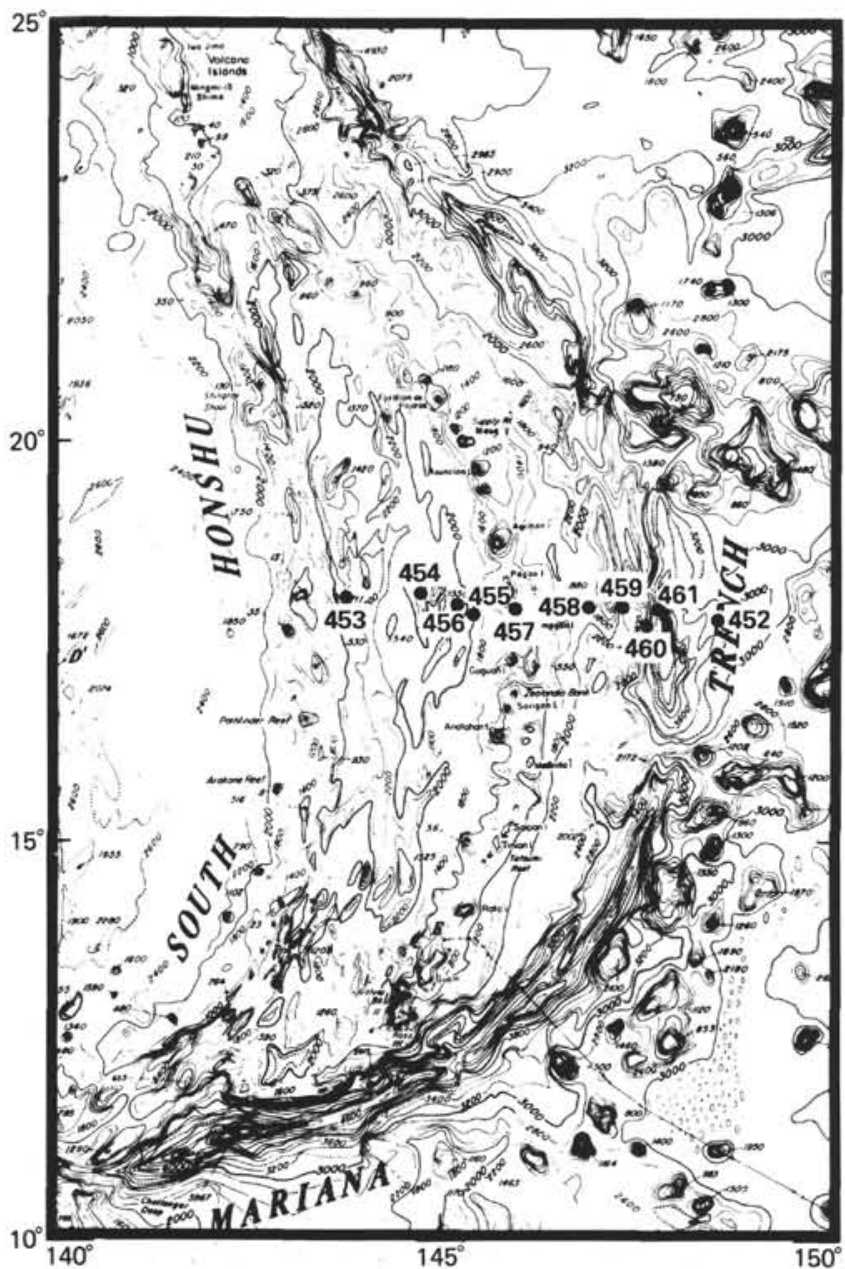

Figure 1. Index map of the South Philippine Sea showing locations of Deep Sea Drilling Project Sites 452 through 461 drilled during Leg 60.

abundant. Refractive indices may vary in a single sample up to 0.07 , but variation may be as little as 0.015 , even in samples with abundant glass (e.g., Samples 453-21, CC, 17-18 cm and 453-22-1, 13-14 cm). A tentative broad correlation of refractive index with chemical composition (percentage of $\mathrm{SiO}_{2}$ ) is shown in Figure 5 , which suggests a large range in volcanic rock composition, from basalt to rhyolite.

\section{COLOR}

Four color shades of shards occur in the analyzed samples. Practically all shards with R.I. $<1.530$ are colorless. Those between R.I. 1.530 and 1.560 are dominantly light brown, with some colorless shards in the range 1.530 to 1.545 . Light brown shades extend to R.I. about 1.580 , but most shards with R.I. $>1.560$ are brown. Shards with greenish shades are in the same range as light brown (1.535-1.570).

It is well known that color of volcanic glass varies with chemical composition and thus with refractive index. Rhyolitic shards are colorless, while basaltic sideromelane shards are light brown. Scheidegger et al. (1978), for example, noted a change in color of glass shards from DSDP Site 192 from colorless (R.I. 1.500) to light brown (R.I. 1.530).

\section{SHARD SHAPE}

Shards were classified into three major groups:

Tubular pumice. These are generally elongate pumice clasts with tubular vesicles in subparallel alignment. They are most abundant in populations with R.I. $<1.550$, but some have R.I. up to 1.580 .

Cuniform shards. Nearly vesicle-free cuniform to angular shards dominate at higher refractive indices, but range down to very low R.I.

Bubble-junction, bubble-wall shards. Shards representing the glass septa of, or thicker junctions between, vesicles are commonly regarded as the typical shard form, but they are slightly less abundant in the analyzed samples than the two other forms listed above, and have a wide range in refractive indices.

\section{DISCUSSION}

Shards of ash-rich sediments recovered in seven holes during Leg 60 have a very wide range in shapes, color, refractive indices and, consequently, in composition. There is excellent correlation between color and refractive index. Using the relationship between refractive index of Williams et al. (1954) and Scheidegger et al. (1978), shards with $\mathrm{SiO}_{2}$ content higher than about 64 percent are colorless, those with $\mathrm{SiO}_{2}$ from 57 to 64 percent are dominantly light brown with some silica-rich shards being colorless and greenish colors in some samples (Fig. 3). Shards with $\mathrm{SiO}_{2}<$ about 57 percent are almost exclusively brown. The correlation of silica content (via R.I.) with type of shard is poor. Tubular pumice shards are less common than cuniform shards at silica contents below about 57 percent $\mathrm{SiO}_{2}$, but both shard types occur at very low and very high silica contents as well.

The range in silica content in a single population is as high as 20 percent, but may be as low as 2 percent, with most samples ranging from about 2 to 12 percent $\mathrm{SiO}_{2}$. Shards in samples where their volume percentage is low generally have a smaller range in R.I., although some samples with low glass contents (e.g., Core 459B-27) contain glass shards varying widely in R.I.

Sites differ in type of shards. Holes 454, 456, 458, 459B, and the SP site survey cores all contain layers of dominantly basaltic andesitic composition, while ash in Hole 453, the site with most abundant ash-rich sediments, is mainly intermediate to silica-rich in composition. Moreover, ash samples in Hole 453 fall into two groups: a lower group (Cores 39 through 42) with shards of variable composition and an upper group (Cores 11 through 39 ) that show a change from more mafic composition near the base to rhyolitic near the top.

The degree of explosivity and therefore the height of eruption columns and the wider dispersal are known to increase with silica content. For example, Horn et al. (1969), in an extensive study of North Pacific sediment distribution, showed that "white ash" (presumably made up of colorless glass shards) has a far greater areal distribution (within a broad zone 1000 to $1300 \mathrm{~km}$ wide 


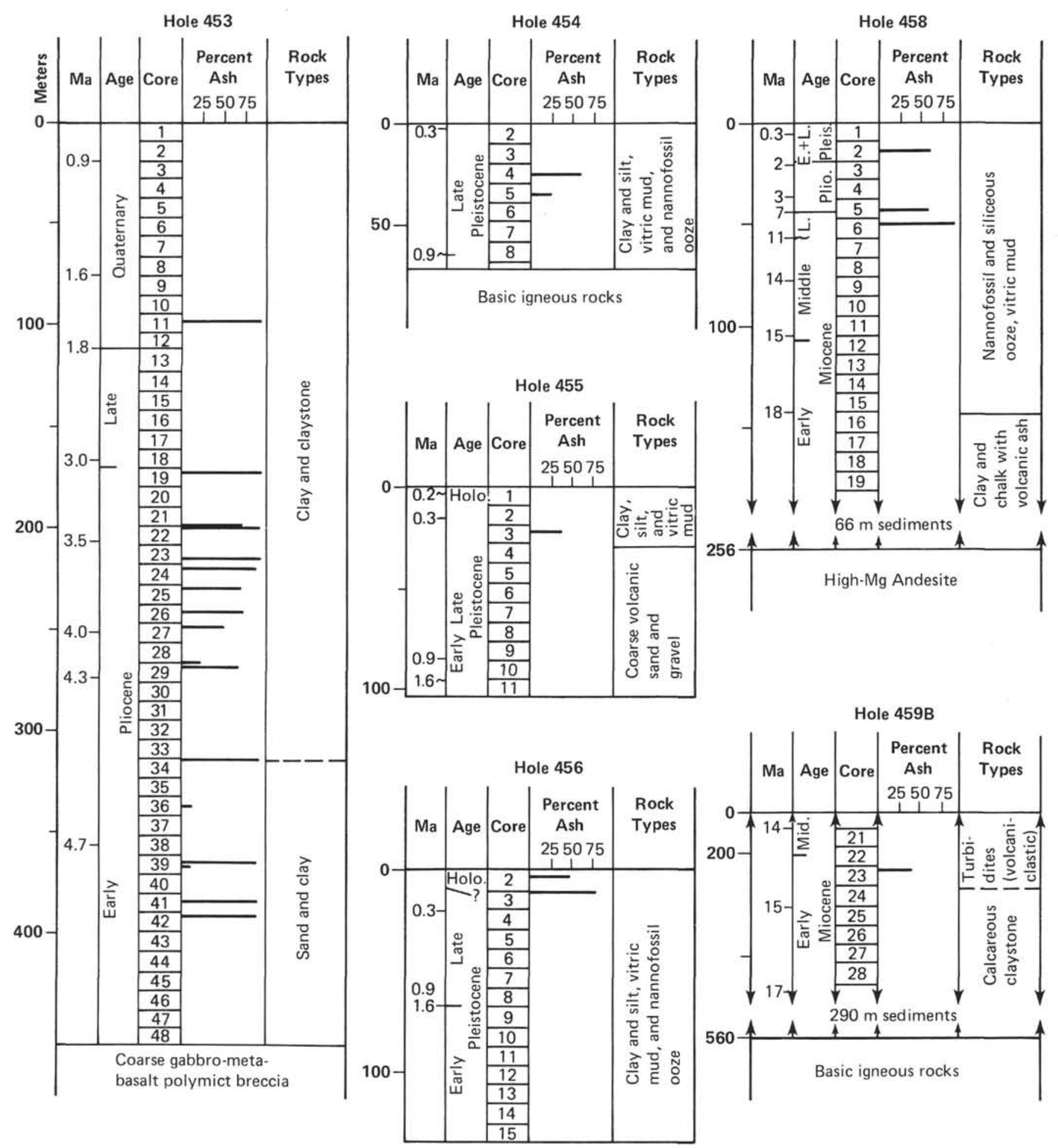

Figure 2. Stratigraphic position and abundance of vitric ash particles in the $65-125 \mu \mathrm{m}$ fraction of samples from six Leg 60 drill sites.

east of Japan, Kuril Islands, and Kamtchataka) than brown ashes occurring chiefly south of the Aleutians and Alaska. It appears from the shipboard descriptions that most, if not all, of the samples studied here are dominantly vitric muds which represent bottom-transported sediments (part of turbidites) rather than distinct ash layers. Even if these are remobilized airborne mate- rials, the shards present in any one sample may be mixed from several eruptions rather than recording a single explosive event. Thus, their usefulness for interpreting volcanic processes is limited.

The shipboard party noted that vitric components strongly decreased in the upper part of Hole 453 (Quaternary sediments) and interpreted this as recording in- 
Table 1. Stratigraphic position, abundance, shape, color, and refractive indices of glass shards of selected samples from Leg 60 vitric muds.

\begin{tabular}{|c|c|c|c|c|c|c|}
\hline $\begin{array}{c}\text { Sample } \\
\text { (interval in } \mathrm{cm} \text { ) }\end{array}$ & $\begin{array}{l}\text { Sample } \\
\text { Weight } \\
\text { (g) }\end{array}$ & $\begin{array}{l}\text { Insoluble } \\
\text { Residue } \\
\text { (g) }\end{array}$ & $\begin{array}{l}\text { Organic and } \\
\text { Carbonatic Materials } \\
\text { (wt. \%) }\end{array}$ & $\begin{array}{l}\text { Dominant Shapes } \\
\text { and Colors }\end{array}$ & Range R.I. & $\begin{array}{c}\text { R.I. of Most } \\
\text { Abundant Shards }\end{array}$ \\
\hline $453-11-3,35-36$ & 3.13 & 2.42 & 22.7 & spl, bj, tp; - & $1.5192-1.5700$ & $1.5331-1.5422$ \\
\hline $19-1,33-34$ & 1.43 & 1.16 & 18.9 & bj, spl, tp; - & $1.4908-1.5110$ & $1.5081-1.5110$ \\
\hline $21, \mathrm{CC}, 17-18$ & 1.24 & 1.05 & 15.3 & bj, spl; - & $1.5097-1.5133$ & $1.5121-1.5133$ \\
\hline $22-1,13-14$ & 1.63 & 1.41 & 13.5 & bj, tp; - & $1.5020-1.5141$ & $1.5102-1.5141$ \\
\hline $23-2,45-46$ & 3.24 & 2.49 & 23.1 & bj, tp; - & $1.5086-1.5610$ & $1.5152-1.5362$ \\
\hline $24-2,48-49$ & 2.07 & 1.88 & 9.2 & tp. bj, spl, - & $1.5157-1.5262$ & $1.5157-1.5262$ \\
\hline $25-1,54-55$ & 5.16 & 4.75 & 11.4 & tp, bj; - & $1.5106-1.5315$ & $1.5249-1.5315$ \\
\hline $26-3,90-91$ & 1.97 & 1.79 & 9.1 & tp, spl, bj; - & $1.5213-1.5415$ & $1.5315-1.5415$ \\
\hline $27-2,41-43$ & 8.03 & 6.95 & 13.5 & spl, bj: - & $1.5110-1.5408$ & $1.5224-1.5408$ \\
\hline $29-1,31-32$ & 2.38 & 2.12 & 10.9 & tp, spl; $-I^{\prime} \mathrm{br}$ & $1.5310-1.5670$ & $1.5310-1.5670$ \\
\hline $29-2,54-55$ & 5.02 & 4,43 & 11.8 & $\mathrm{spl} ;-, 1 \mathrm{br}$ & $1.5158-1.5635$ & $1.5158-1.5635$ \\
\hline $29-2,55-57$ & & & 13.7 & $\mathrm{spl}, \mathrm{tp} ; \mathrm{l}^{\prime} \mathrm{br}$ & $1.5118-1.5720$ & $1.5403-1.5440$ \\
\hline $34-1,24-25$ & 4.62 & 4.24 & 8.2 & tp, spl: l'br & $1.5377-1.5724$ & $1.5377-1.5724$ \\
\hline $36-4,41-42$ & 5.39 & 3.05 & 43.4 & spl; I'br & 1.5549 & 1.5549 \\
\hline $39-3,109-110$ & 2.28 & 2.11 & 7.5 & spl, tp; - & $1.5106-1.5390$ & $1.5189-1.5263$ \\
\hline $39-5,38-39$ & 3.16 & 2.44 & 22.8 & spl, tp; - & 1.4830 & 1.4830 \\
\hline $41-3,42-43$ & 3.19 & 2.89 & 9.4 & spl, tp; - & $1.5097-1.5410$ & $1.5150-1.5228$ \\
\hline $42-1,140-141$ & 3.49 & 3.14 & 10.0 & spl, tp; I'br & $1.5329-1.5770$ & 1.5426 \\
\hline $454-4-4,94-95$ & 2.51 & 2.18 & 13.1 & spl;,$- l^{\prime} b r$ & $1.5188-1.5870$ & $1.5510-1.5870$ \\
\hline $5-4,108-109$ & 1.92 & 1.77 & 7.8 & spl; br & $1.5367-1.5781$ & 1.5791 \\
\hline $12-4,134-135$ & 2.20 & 1.59 & 27.7 & tp. spl; / 1 br & $1.5302-1.5410$ & 1.5410 \\
\hline $12-6,83-84$ & 2.28 & 1.92 & 15.8 & spl, bj: l br & $1.5299-1.5847$ & 1.5472 \\
\hline $455-3-3,20-22$ & 2.15 & 2.08 & 3.3 & spl, tp; - & 1.5053 & 1.5053 \\
\hline $456-2-3,8-9$ & 4.81 & 4,41 & 8.3 & spl, tp: l'br & 1.5484 & 1.5484 \\
\hline $3-1,30-31$ & 3.61 & 3.15 & 12.7 & spl, tp. bj: I'br & $1.5227-1.5796$ & $1.5641-1.5796$ \\
\hline $458-2-4,30-31$ & 2.79 & 1.78 & 36.2 & tp. bj: I'br & $1.5613-1.5744$ & $1.5613-1.5744$ \\
\hline $5-4,89-90$ & 3.69 & 3.28 & 11.1 & spl, bj: - & $1.4990-1.5199$ & $1.5107-1.5199$ \\
\hline $6-2,63-64$ & 3.18 & 2.91 & 8.5 & tp. $b j:-$ & $1.5093-1.5414$ & $1.5293-1.5414$ \\
\hline $\begin{array}{c}459 \mathrm{~B}-24-2,20-22 \\
27-1,40-41\end{array}$ & 12.54 & 11.60 & 7.4 & spl, tp: gr. -, br & $1.5310-1.5690$ & $\begin{array}{c}1.5690 \\
1.569\end{array}$ \\
\hline $27-1,40-41$ & 2.91 & 2.47 & 15.1 & spl, tp; -, br & $1.5045-1.5711$ & $.5045-1.5310$ \\
\hline SP-1A-1, 67-68 & 2.69 & 1.97 & 26.8 & spl, - & 1.5082 & 1.5082 \\
\hline $4 E-2,31-32$ & 3.37 & 3.06 & 9.2 & spl, bj: -, br & $1.5148-1.5805$ & $1.5755-1.5805$ \\
\hline
\end{tabular}

Notes: $5 \mathrm{pl}=$ spallation $\left(\right.$ cuniform) shard; $\mathrm{bj}=$ bubble junction shard; $\mathrm{tp}=$ tubular pumice shard; $-=$ colorless; $\mathrm{I}^{\prime} \mathrm{br}=$ light brown; br $=$ brown; $\mathrm{gr}=$ greenish

creasing distance from the Mariana arc due to widening of the Mariana Trough. Site 453 is about $120 \mathrm{~km}$ west of the present trough axis and about $300 \mathrm{~km}$ west of the active arc. Increasing distance from the active arc may also be reflected in the change in composition from more mafic to rhyolitic composition from Cores 36 to 19 (about 4.6 to $3.0 \mathrm{Ma}$ ), especially if the rhyolitic ash particles are derived from highly explosive eruptions contrasting with more local derivation of basaltic glass particles. Alternatively, or in addition, the upward change in compositional diversity may record a change from a wide range in calc-alkaline magma compositions to a bimodal rhyolite-basalt suite at the source arc.

The question whether increasing numbers of ash layers in younger sediments record increase in volcanic activity or movement of the site of deposition toward a volcanic source has been the subject of much recent discussion. Site 453 may record the opposite effect: as the site of deposition moves away from active volcanoes, ash changes toward more silicic composition and finally disappears upward in the sedimentary column. The alternative, that the change in ash compositions reflects changes in composition at the source, cannot be evaluated because of a lack of data at the source. As a further speculation, the abundance of rhyolitic material in
Holes 458, 459B, and the SP site survey cores, all east of the Mariana arc, may record the dominance of westerly winds.

In view of the fact that all samples studied represent only a minute fraction of thick sedimentary sections dominated by vitric components, the interpretations are highly tentative.

\section{ACKNOWLEDGMENTS}

Work on Deep Sea Drilling rocks is supported by the Deutsche Forschungsgemeinschaft (Grants Schm 250/22 and Schm 250/24), which is gratefully acknowledged. Rolf Neuser carefully measured refractive indices. Thanks are due to $R$. V. Fisher for reviewing the paper and to $\mathrm{U}$. Bleil for providing the samples.

\section{REFERENCES}

Horn, D. R., Delach, M. N., and Horn, B. M., 1969. Distribution of volcanic ash layers and turbidites in the North Pacific. Geol. Soc. Am. Bull., 80:1715-1724.

Scheidegger, K. F., Jezek, P. A., and Ninkovich, D., 1978. Chemical and optical studies of glass shards in Pleistocene and Pliocene ash layers from DSDP Site 192, northwestern Pacific Ocean. $J$. Volcanol. Geotherm. Res., 4:99-116.

Schmincke, H.-U., and Medenbach, O., in preparation. Ashes from Leg 56.

Williams, H., Turner, F. J., and Gilbert, C. M., 1954. Petrography: San Francisco (Freeman \& Co). 

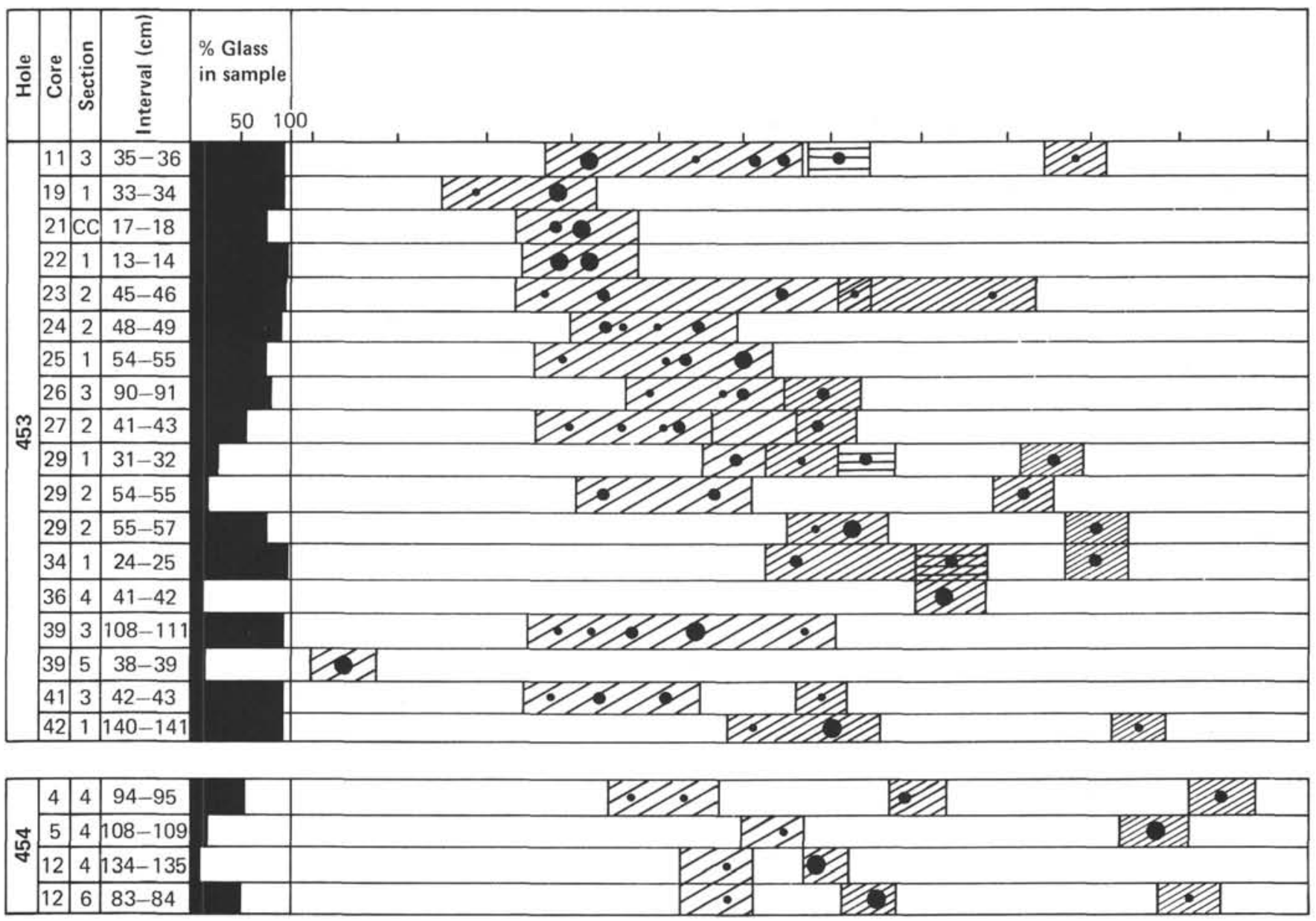

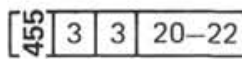

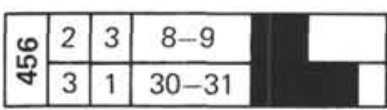
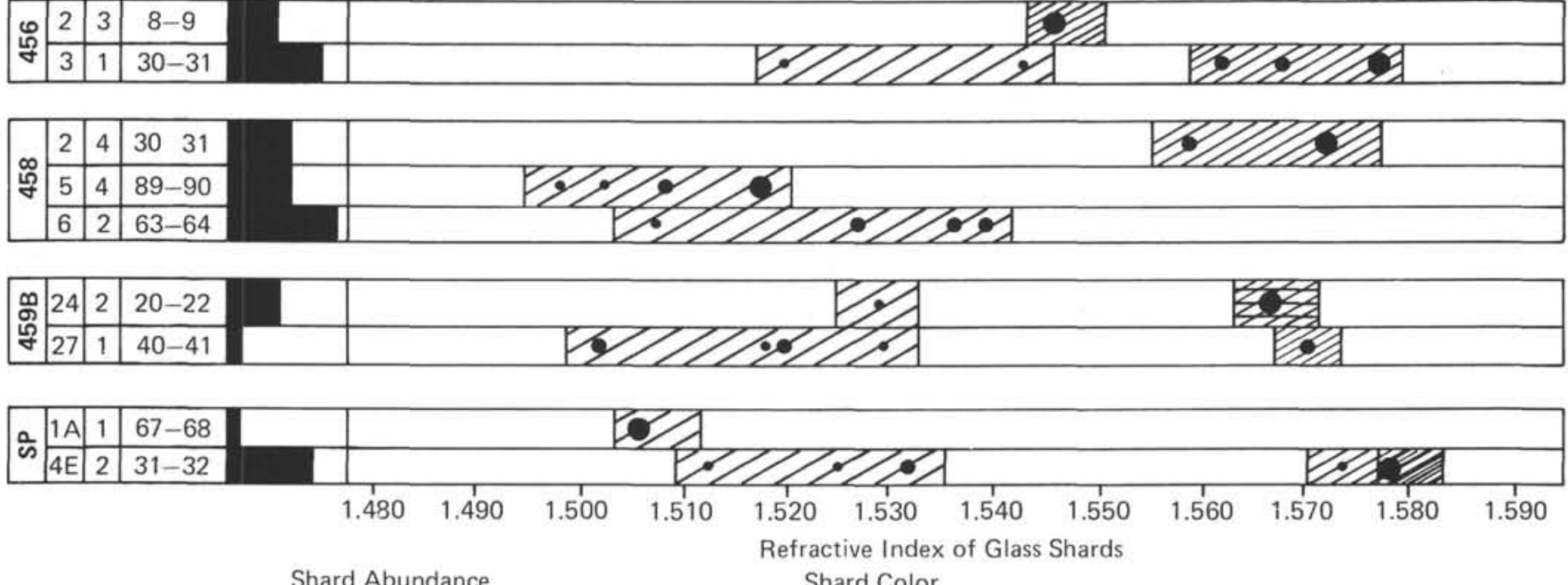

Shard Abundance Shard Color
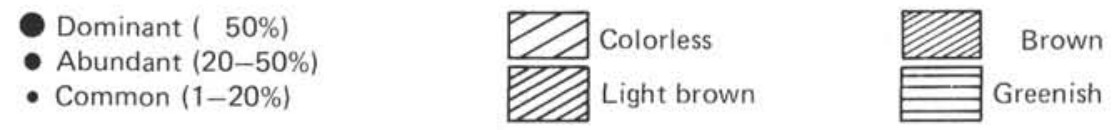

Figure 3. Range and abundance of refractive indices and color of glass shards from vitric muds in seven Leg 60 sites. 

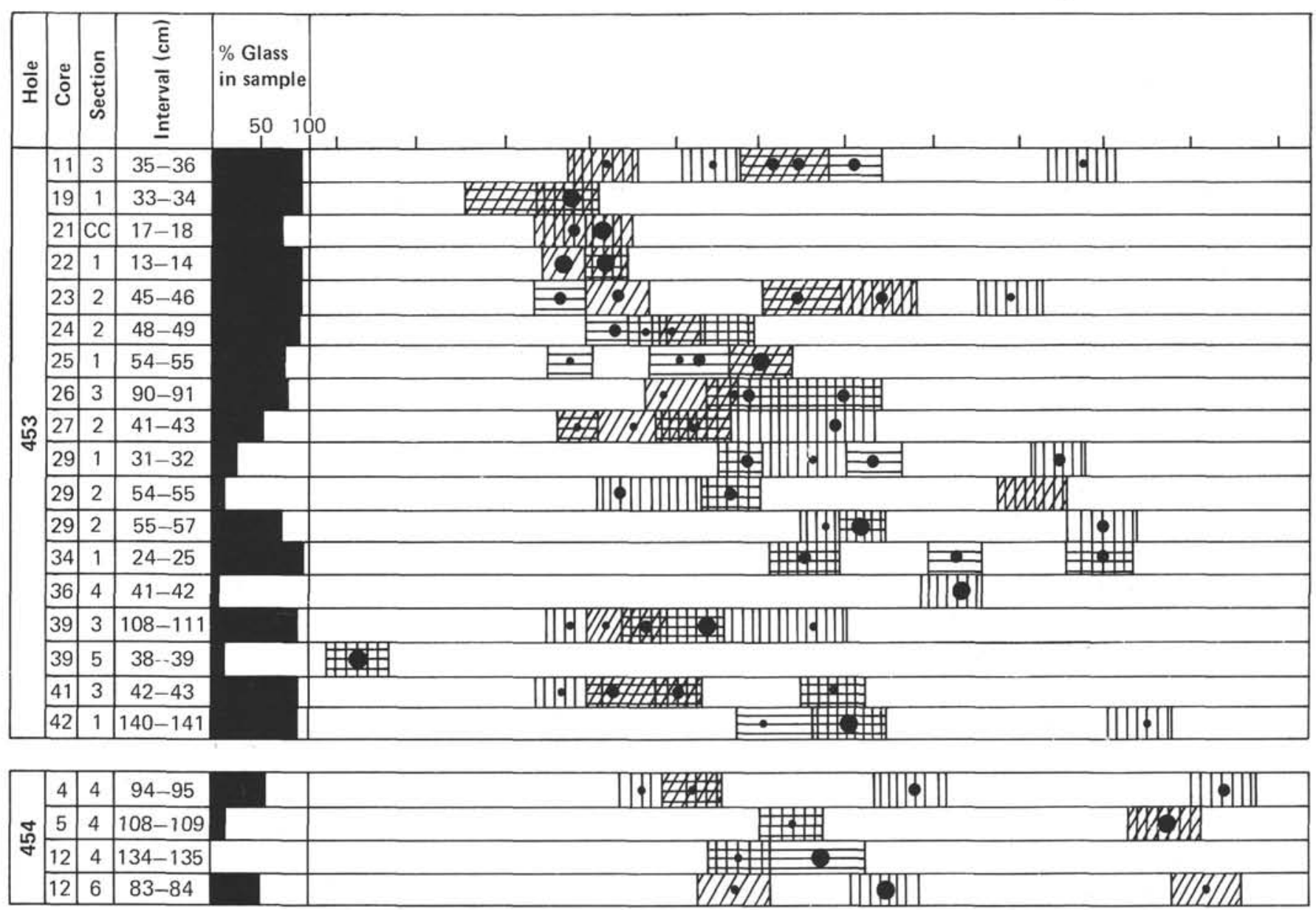

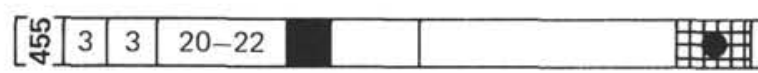
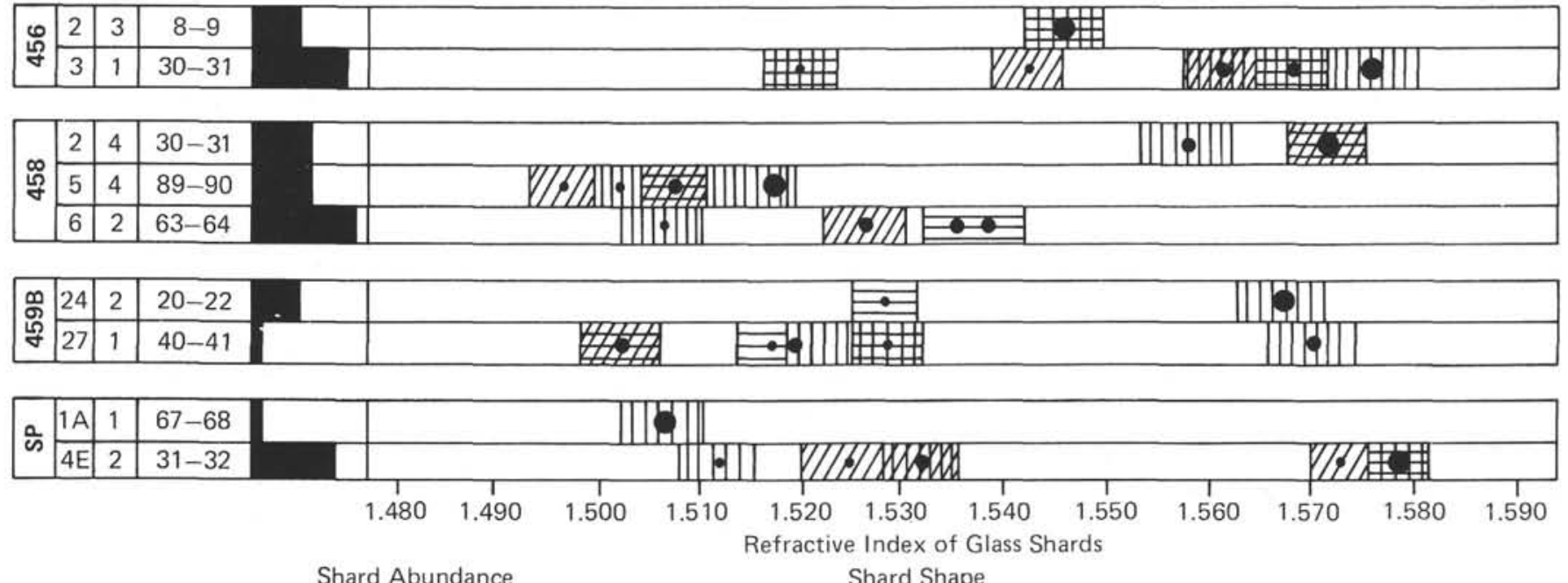

Shard Abundance

Dominant ( $50 \%)$

- Abundant $(20-50 \%)$

- Common (1-20\%)
Shard Shape

VIIID Bubble junction, bubble wall

ШाI Spallation, cuniform

Tubular pumice

Figure 4. Shape and refractive indices of glass shards from vitric muds in seven Leg 60 sites. 


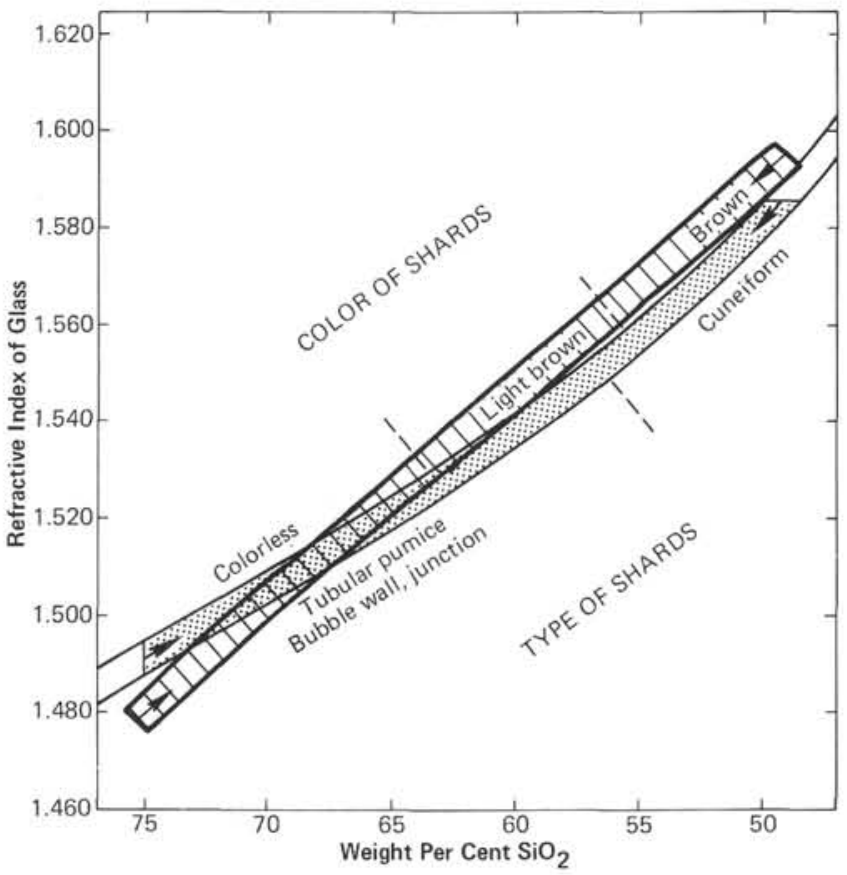

Figure 5. Approximate correlation of refractive index and $\mathrm{SiO}_{2}$ content of glass shards based on data by Williams et al. (1954), Scheidegger et al. (1978), and the present study. Also shown are dominant colors and shapes of shards from Leg 60 volcanic sediments. Arrows show extent of refractive indices measured. 


\section{H.-U. SCHMINCKE}

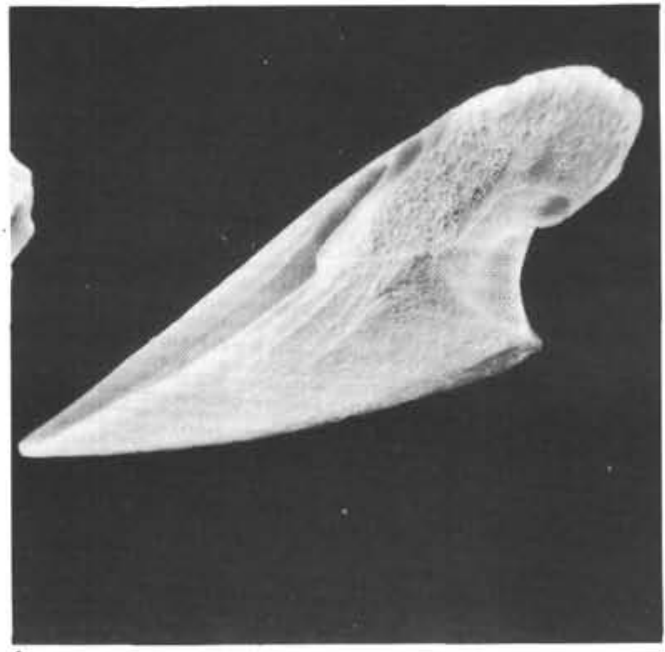

1

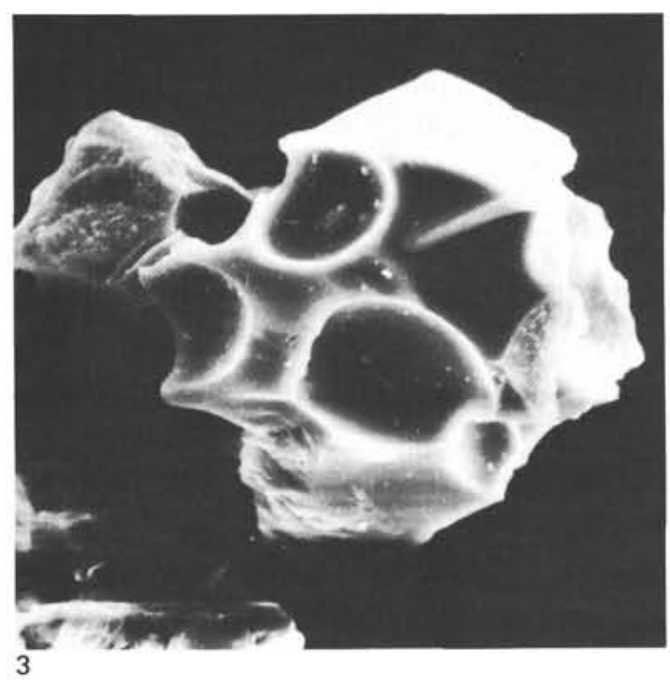

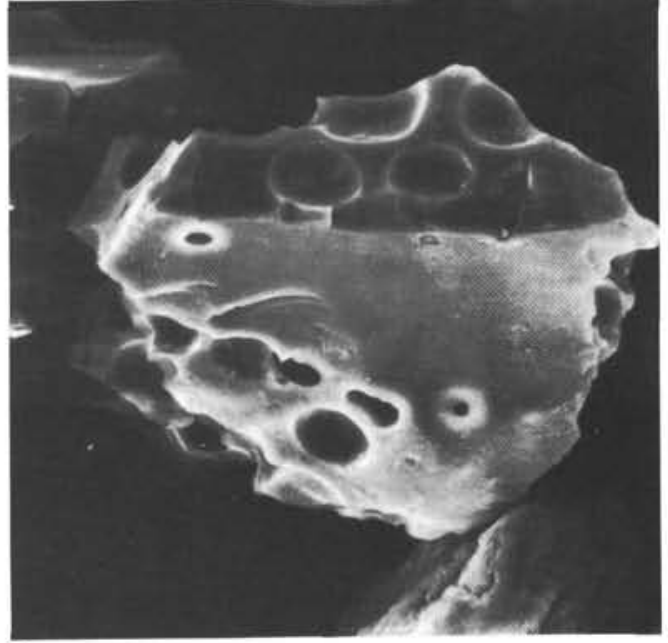

2

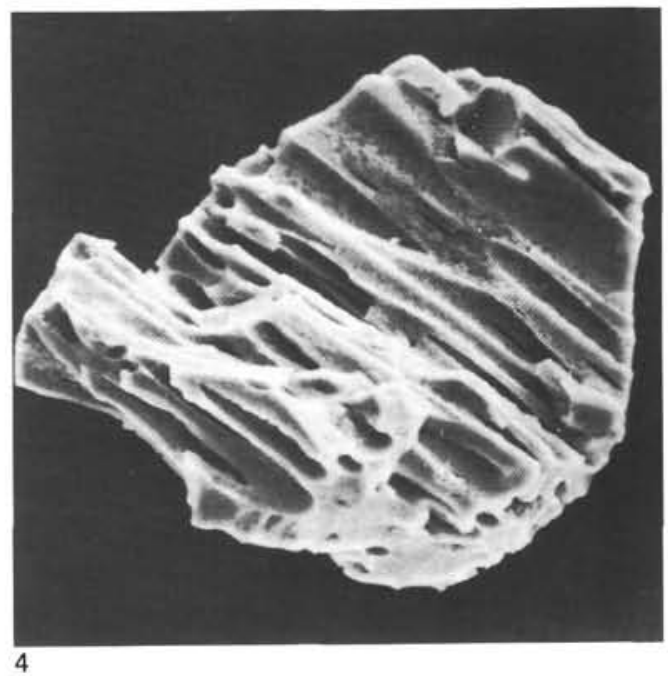

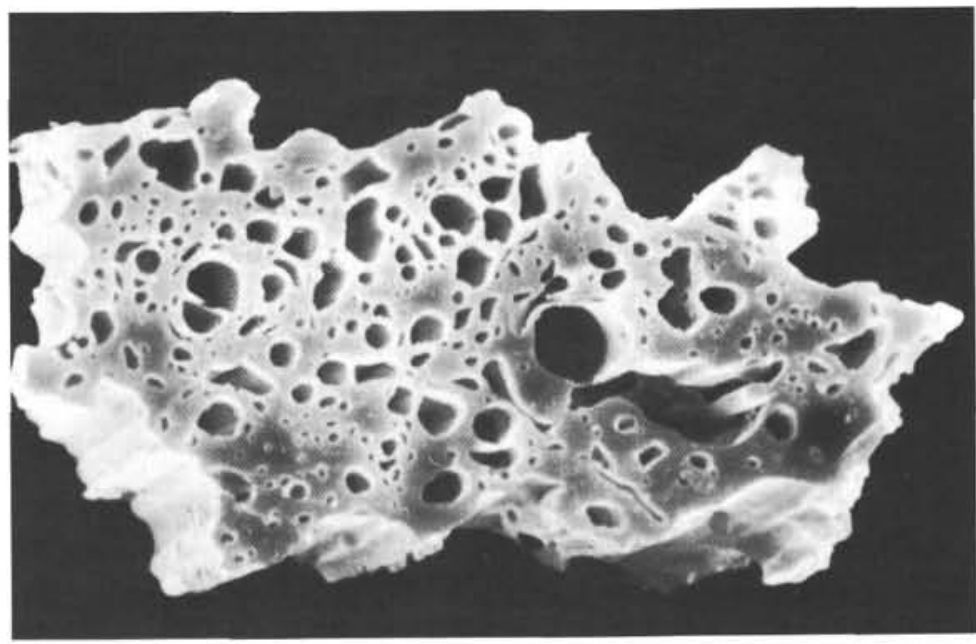

5

Plate 1. Characteristic shapes and internal structures of glass shards studied (bar scale $=50 \mu \mathrm{m}$ ).

Figure 1. Cuniform shard.

Figure 2. Blocky shard with sparse vesicles.
Figure 3. Blocky shard with thick glass septa.

Figure 4. Tubular vesicles in highly vesicular shard.

Figure 5. Cross section of tubular pumice shard. Note deformed vesicles around larger diameter vesicles. 

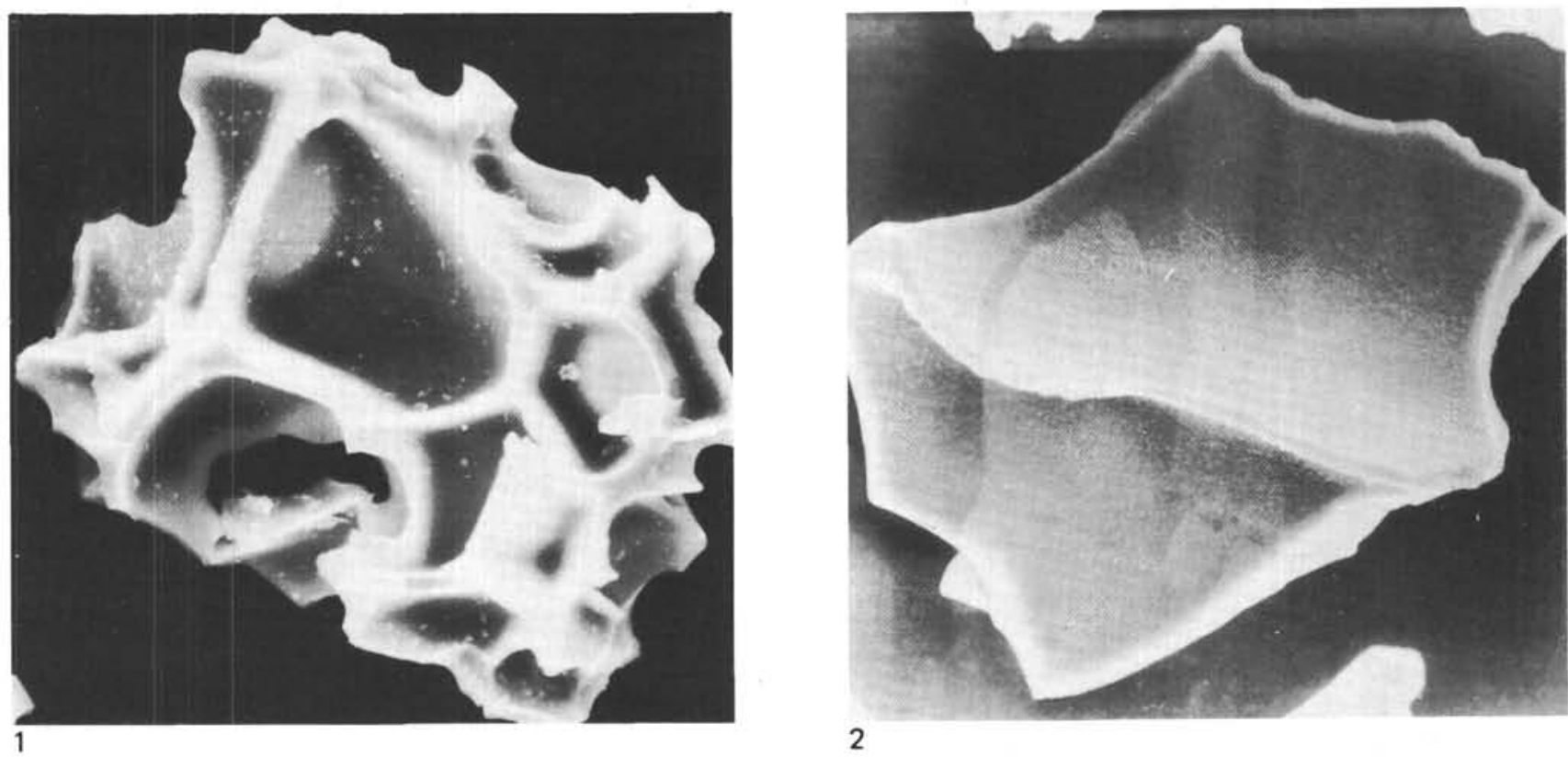

2

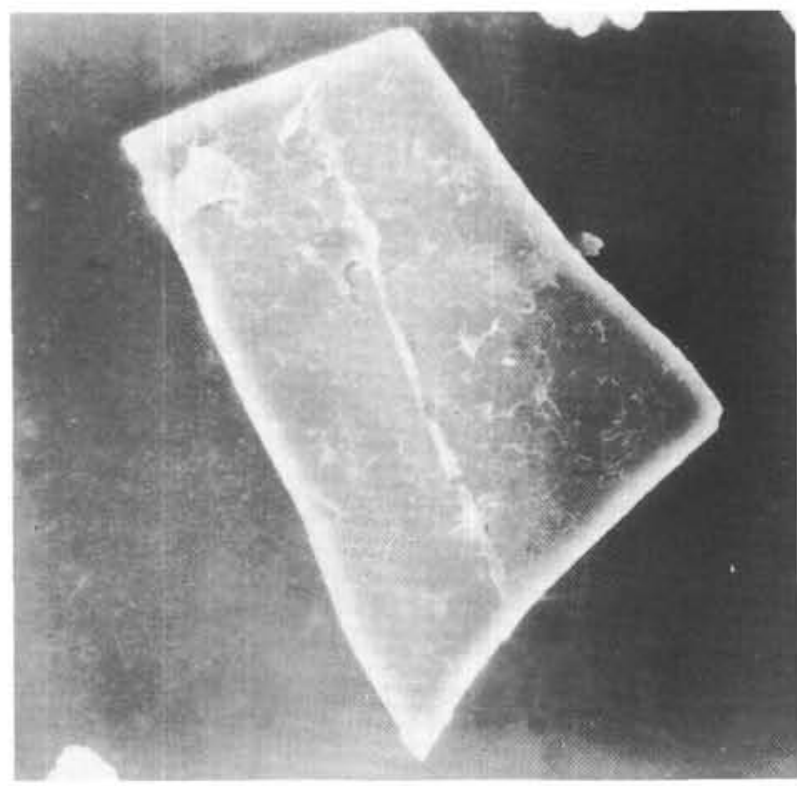

3

Plate 2. Characteristic shapes and internal structures of glass shards studied (bar scale $=50 \mu \mathrm{m}$ ).

Figure 1. Pumice shard with subspherical to elongate vesicles.

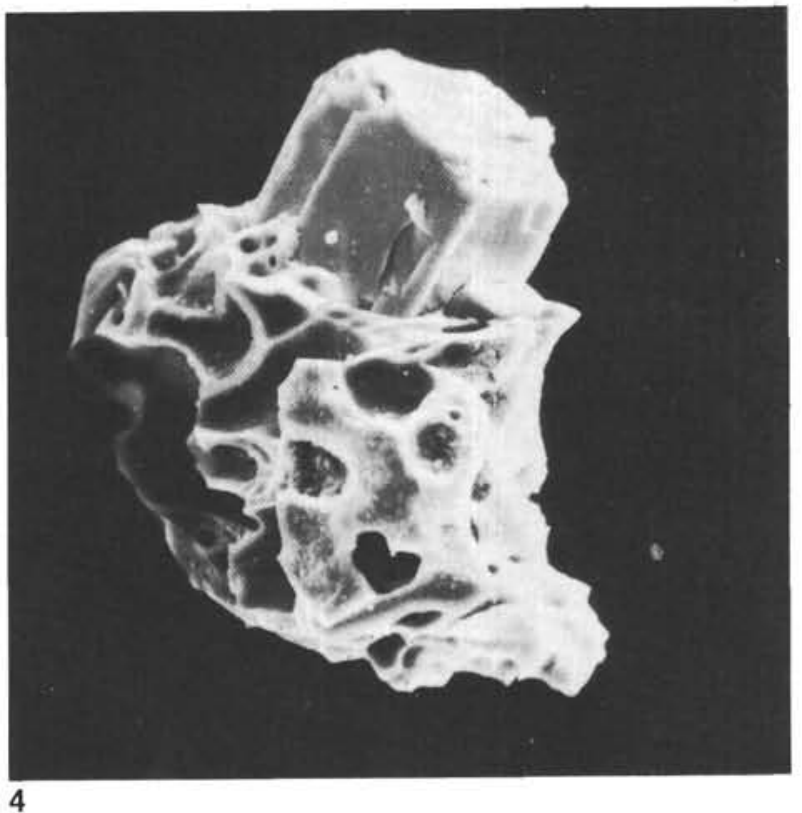

Figure 2. Bubble junction shard.

Figure 3. Platy shard.

Figure 4. Pumice shard with phillipsite crystal. 